\section{'Nacono' Pecan}

\section{Tommy E. Thompson ${ }^{1}$ and L.J. Grauke ${ }^{2}$}

Pecan Genetics and Breeding Program, Agricultural Research Service, U.S. Department of Agriculture, Route 2, Box 133, Somerville, TX 77879

Additional index words. Carya illinoinensis, cultivar, breeding, genetics
'Nacono' is a pecan [Carya illinoinensis (Wangenh.) K. Koch] cultivar released 18 July 2000 by the Agricultural Research Service (ARS) of the U.S. Dept. of Agriculture (USDA), and the Texas Agricultural Experiment Station. Compared to other protogynous cultivars, 'Nacono' has superior nut quality. 'Nacono' has moderate resistance to scab [Cladosporium caryigenum (Ell. et Lang.) Gottwald], and is suitable for planting in most cans are large enough to be sold in-shell, or they can be shelled to produce a high proportion of intact halves and large pieces of very high quality.

\section{Origin}

The USDA conducts the only national pecan breeding program. Crosses are made at Brownwood and College Station, Texas (Grauke and Thompson, 1996; Thompson and Grauke, 1991; Thompson and Young, 1985). Seedling clones are established on their own roots or budded onto pollarded trees for the initial testing at College Station for $\approx 10$ years. Superior clones then enter the National Pecan Advanced Clone Testing System (NPACTS), where they are tested across the southern United States. After 10 to 15 years, the best clones are given Native American tribe names and released to nurseries. 'Nacono' is the 24th cultiwith various state agricultural experiment stations. All USDA cultivars (with the exception of 'Barton') have Native American tribe names. The Nacono tribe was part of the southern Caddo Confederacy, and lived near the Neches River in East Texas (near the Lufkin area). This name was chosen to associate the cultivar name with a geographic region where we think this new cultivar will perform well, an area that includes the humid southeastern region of the United States.

'Nacono', tested as selection 74-5-55, is a progeny from a 1974 cross between the 'Cheyenne' and 'Sioux' cultivars made by E.J. Brown at the USDA Pecan Worksite, Brownwood, Texas. 'Cheyenne' is a USDA cultivar released in 1970 (Brooks and Olmo, 1970). It is known as the producer of the highest quality kernels of any cultivar. It is resistant to scab,

Received for publication 18 Sept. 2000. Accepted for publication $4 \mathrm{Apr}$. 2001. The cost of publishing this paper was defrayed in part by the payment of page charges. Under postal regulations, this paper therefore must be hereby marked advertisement solely to indicate this fact.

${ }^{1}$ Research Geneticist.

${ }^{2}$ Research Horticulturist. U.S. pecan-production areas. 'Nacono' pevar released by this program in cooperation but very susceptible to the blackmargined aphid (Monellia caryella Fitch) and the yellow pecan aphid (Monelliopsis pecanis Bissell). 'Sioux' was released by the USDA in 1962 (Brooks and Olmo, 1962). It is also known for high nut quality and scab resistance. 'Sioux' is not as precocious as 'Cheyenne', and the nuts are smaller (Grauke and Thompson, 1997). 'Nacono' was released based upon the extensive testing in the replicated NPACTS test at College Station, Texas.

\section{Description}

'Nacono' has precocity similar to 'Pawnee' and 'Desirable', but outyielded these cultivars in the 10th season (Table 1). The high (1993) and 10th (1995) leaf are partially the result of large tree size compared to 'Pawnee' and 'Desirable' (Table 2). The 10th-year yield would convert to $\approx 1930 \mathrm{~kg} \cdot \mathrm{ha}^{-1}$ with the spacing $10.7 \times 10.7 \mathrm{~m}$. Uniformity of production of 'Nacono' across years is largely unknown. NPACTS-B (Tables 1, 2, and 3) was essentially an unirrigated test since we did not have the capacity to water it adequately, especially during high-water-requirement periods. Trees experienced a severe drought during the latter part of 1993, followed by an early freeze of $2{ }^{\circ} \mathrm{C}$ on 31 Oct. 1993 , that damaged the still foliated trees. Carbohydrate reserves were probably also extremely low due to drought and heavy nut load, so freeze damage was severe on many trees of other clones. Limbs of 'Nacono' were not damaged, but this resulted in very low yield in 1994 for all trees in the test. We know that throughout this test period, 'Nacono' excelled in producing a large quantity of quality nuts, even considering these environmental challenges.

When fruit number per cluster is compared with that of control cultivars (Table 2), yields shown in Table 1 during the eighth

Table 1. National Pecan Advanced Clone Testing System yield data from College Station, Texas. ${ }^{\mathrm{Z}}$

\begin{tabular}{lcccccccr}
\hline & \multicolumn{7}{c}{ Nut yield $(\mathrm{kg} /$ tree $)$} \\
\cline { 2 - 9 } Cultivar & 1989 & 1990 & 1991 & 1992 & 1993 & 1994 & 1995 & Total \\
\hline Nacono & 0.0 & 0.0 & 0.2 & 0.3 & 9.5 & 0.4 & $22.1 \mathrm{a}^{\mathrm{y}}$ & $32.6 \mathrm{a}$ \\
Pawnee & 0.0 & 0.2 & 0.2 & 0.2 & 8.5 & 1.2 & $12.4 \mathrm{~b}$ & $22.6 \mathrm{a}$ \\
Desirable & 0.0 & 0.3 & 1.3 & 1.5 & 4.7 & 1.0 & $13.9 \mathrm{~b}$ & $22.8 \mathrm{a}$ \\
Stuart & 0.1 & 0.1 & 0.2 & 0.3 & 3.3 & 1.2 & $12.4 \mathrm{c}$ & $17.5 \mathrm{~b}$
\end{tabular}

${ }^{\mathrm{z}}$ Means of five single-tree replicates, with clones grafted on established open-pollinated rootstocks in Apr. 1986. Yield differences were nonsignificant $(P<0.05)$ for years 1989-94.

y Means in columns with no common letters are different according to Duncan's multiple range test $(P<0.05)$.

Table 2. National Pecan Advanced Clone Testing System data from College Station, Texas, comparing 'Nacono' to other cultivars for tree characteristics. Clones grafted on established open-pollinated rootstocks in Apr. 1986.

\begin{tabular}{lcccc}
\hline & \multicolumn{4}{c}{ Cultivar } \\
\cline { 2 - 5 } Characteristic $^{\mathrm{z}}$ & Nacono & Pawnee & Desirable & Stuart \\
\hline Budbreak & $1.5 \mathrm{a}^{\mathrm{y}}$ & $1.7 \mathrm{a}$ & $1.6 \mathrm{a}$ & $1.0 \mathrm{~b}$ \\
Leaf scab & 1.7 & 1.7 & 2.2 & 1.8 \\
Nut scab & $1.7 \mathrm{c}$ & $3.7 \mathrm{a}$ & $2.8 \mathrm{~b}$ & $1.4 \mathrm{c}$ \\
Blackmargined aphids & $0.6 \mathrm{a}$ & $0.2 \mathrm{~b}$ & $0.3 \mathrm{~b}$ & $0.5 \mathrm{a}$ \\
TCA $\left(\mathrm{dm}^{2}\right)$ & 5.8 & 3.3 & 3.4 & 4.3 \\
Fruits/cluster & $2.8 \mathrm{~b}$ & $3.5 \mathrm{a}$ & $2.4 \mathrm{c}$ & $2.1 \mathrm{c}$ \\
Terminals with clusters $(\%)$ & 19.8 & 28.3 & 29.0 & 19.1
\end{tabular}

${ }^{\mathrm{Z}}$ Budbreak ratings (1989) according to a 1-5 scale, with $1=$ dormant and $5=$ leaf expansion Clone with smallest number is latest. Leaf and nut scab ratings (1993) $1-5,1=$ most resistant (Hunter and Roberts, 1978). Mean number of blackmargined aphids on leaflets 4 and 5 (Thompson and Grauke, 1998). TCA = trunk cross-sectional area recorded 14 Mar. 1996. Fruits/cluster and terminals with clusters are means across 3 years (1993-95).

${ }^{y}$ Means in rows with no common letters are different according to Duncan's multiple range test $(P<0.05)$. Absence of letters indicates absence of treatment statistical differences.

Table 3. National Pecan Advanced Clone Testing System data from College Station, Texas, comparing 'Nacono' to other cultivars for nut characteristics. Each mean is the average for 3 years and five replications of 10 nut samples.

\begin{tabular}{lrrrr}
\hline & \multicolumn{4}{c}{ Cultivar } \\
\cline { 2 - 5 } Characteristic & Nacono & Pawnee & Desirable & Stuart \\
\hline Nut weight $(\mathrm{g})$ & $10.5 \mathrm{a}^{\mathrm{z}}$ & $8.3 \mathrm{c}$ & $9.2 \mathrm{~b}$ & $8.9 \mathrm{bc}$ \\
Kernel $(\%)$ & $57.1 \mathrm{~b}$ & $59.9 \mathrm{a}$ & $54.6 \mathrm{c}$ & $48.1 \mathrm{~d}$ \\
Kernel color $^{\mathrm{y}}$ & $2.2 \mathrm{~b}$ & $3.1 \mathrm{a}$ & $2.9 \mathrm{a}$ & $3.2 \mathrm{a}$
\end{tabular}

${ }^{\mathrm{z}}$ Means in rows with no common letters are different according to Duncan's multiple range test $(P<0.05)$.

${ }^{y}$ Kernel color is on a $1-10$ scale, with 1 being the lightest (most desirable) color 
'Nacono' is intermediate between Pawnee' and 'Desirable'. 'Nacono' has about the same number of terminals with clusters as the control cultivars.

'Nacono' produces a large nut of exceptional quality (Fig. 1 and Table 3). Nut shape is oblong with acute apex, and an acuminate (pointed) base. Nuts are round in cross section. Dorsal grooves are wide, allowing easy removal of packing material. The dorsal groove and basal cleft of 'Nacono' are almost absent, similar to that of the 'Sioux' parent.

Nut weight is $\approx 10.5 \mathrm{~g}$, larger than 'Pawnee', 'Desirable', or 'Stuart'. Nuts have $\approx 57 \%$ kernel, between 'Pawnee' and 'Desirable'. 'Nacono' is an easy-shelling pecan, and produces a high proportion of complete or nearcomplete halves. Kernels are cream to golden in color, and are lighter than the control cultivars (Table 3).

'Nacono' trees are vigorous, with a branched central leader form that is similar to its 'Sioux' parent. 'Nacono' develops strong limb angles which are wind-resistant. 'Nacono' grows more rapidly than other cultivars (Table 2 ). The leaves are large, similar to those of 'Sioux' and other individuals of this cross family (74-5-60 and 75-5-6).

Time of spring budbreak is similar to that of 'Pawnee' and 'Desirable' (Table 2). 'Nacono' is protogynous (Type II), with early pistil receptivity and midseason pollen shed (Fig. 2). 'Nacono' should be a good pollinizer for, and well-pollenized by 'Pawnee', 'Desirable', and 'Cheyenne'. Time of nut maturity is midseason at College Station (11-21 Oct.), or $\approx 8$ d before 'Desirable' and 12 d before 'Stuart'.

'Nacono' is moderately resistant to scab disease, and should be adapted to all pecangrowing areas where 'Desirable' can be grown, especially under a typical chemical scab-control program. In tests at College Station (Table 2), 'Nacono' appeared to have about the same level of leaf scab resistance as the control cultivars, but was significantly more resistant to nut scab than 'Pawnee' and 'Desirable'.

'Nacono' has medium susceptibility to blackmargined aphids (Thompson and Grauke, 1998). At College Station, 'Nacono' and 'Stuart' demonstrated similar resistance to this insect, but these two cultivars were less resistant than 'Pawnee' and 'Desirable'. Since susceptibility to one species of aphids in pecan seems to indicate susceptibility to another species (Kaakeh and Dutcher, 1994), growers should monitor black aphid susceptibility in this new cultivar.

\section{Availability}

Budwood and graftwood will be supplied in 2001 only to nurseries. All requests should be directed to the senior author. The USDA does not have trees for distribution. Some budded or grafted trees should be available from nurseries for planting in early 2002 .

\section{Literature Cited}

Brooks, R.M. and H.P. Olmo. 1962. Register of new fruit and nut varieties. List 17. Proc. Amer. Soc.

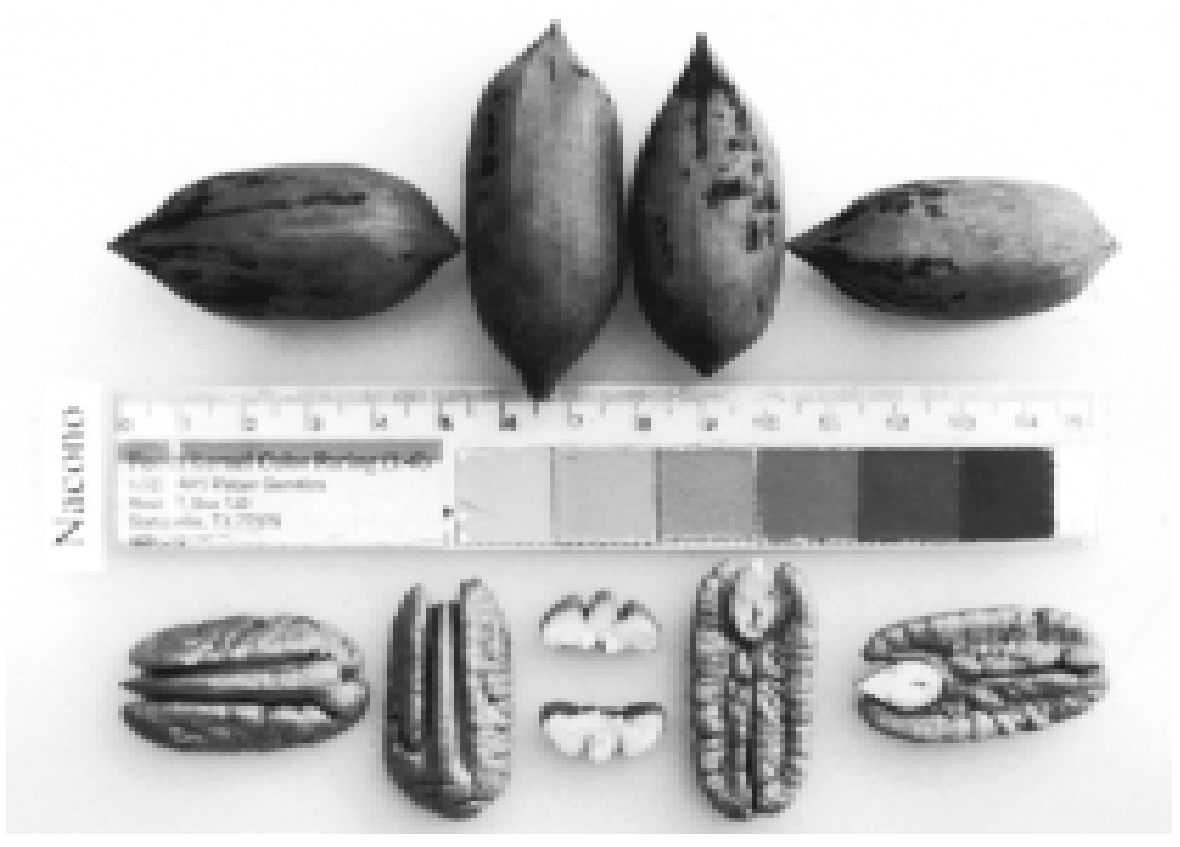

Fig. 1. Nuts and kernels of 'Nacono' pecan. The scale is in cm.

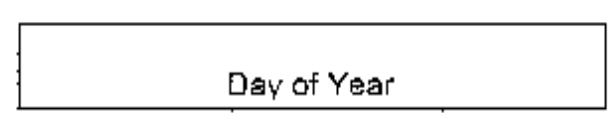

$100 \quad 110 \quad 120$

130

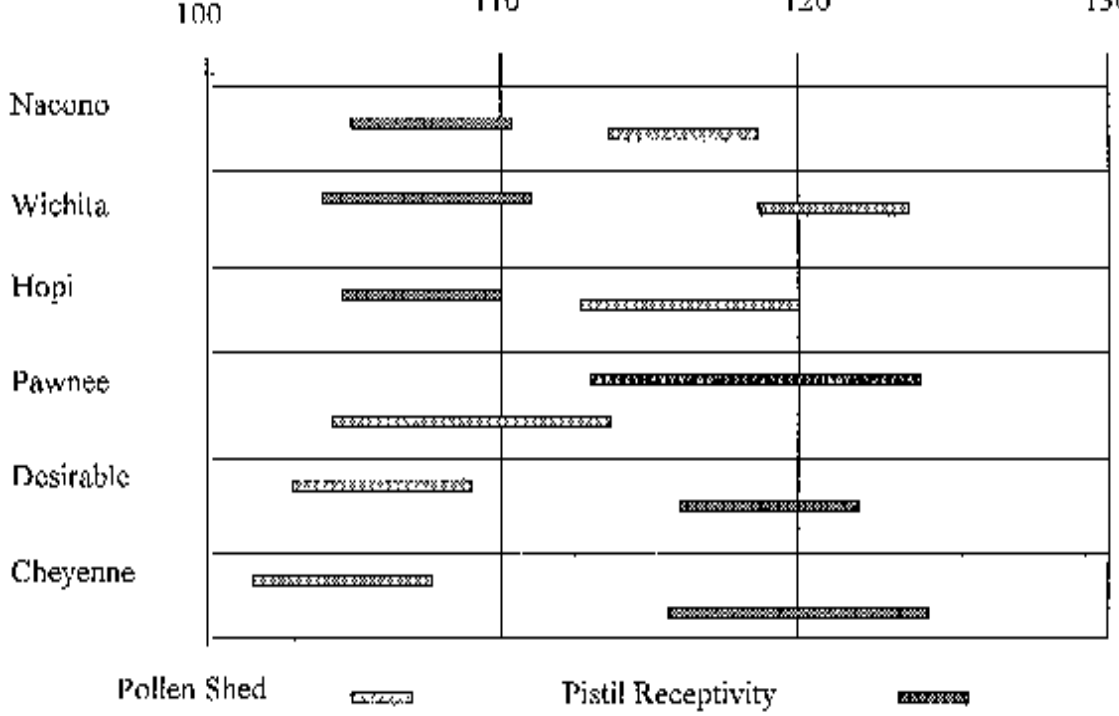

Fig. 2. Pollen shed and pistil receptivity for 'Nacono' pecan and check cultivars at College Station, Texas, in 1999.

Hort. Sci. 81:568-600.

Brooks, R.M. and H.P. Olmo. 1970. Register of new fruit and nut varieties. List 25. HortScience 5:383-390.

Grauke, L.J. and T.E. Thompson. 1996. Pecans and hickories, p. 185-239. In: J.A. Janick and J.N. Moore (eds.). Fruit breeding. III. Nuts. Wiley, New York.

Grauke, L.J. and T.E. Thompson. 1997. Pecan, p. 544-562. In: The Brooks and Olmo register of fruit and nut varieties. Amer. Soc. Hort. Sci., Alexandria, Va.

Hunter, R.E. and D.D. Roberts. 1978. A disease grading system for pecan scab. Pecan Quarterly 12:3-6.

Kaakeh, W. and D. Dutcher. 1994. Probing behavior and density of Monelliopsis pecanis, Monellia caryella, and Melanocallis caryaefoliae (Homoptera: Aphididae) on pecan cultivars. J. Econ. Entomol. 87:951-956.

Thompson, T.E. and L.J. Grauke. 1991. Pecans and other hickories (Carya), p. 839-904. In: J.N. Moore and J.R. Ballington (eds.). Genetic resources of temperate fruit and nut crops. Intl. Soc. Hort. Sci., Wageningen, The Netherlands.

Thompson, T.E. and L.J. Grauke. 1998. Field resistance to yellow aphids in pecan. J. Amer. Soc. Hort. Sci. 123:85-90.

Thompson, T.E. and E.F. Young, Jr. 1985. Pecan cultivars: Past and present. Texas Pecan Growers Assn., College Station. 